\title{
The energy value of short-chain fatty acids infused into the caecum of pigs
}

\author{
BY HENRY JØRGENSEN, TORBEN LARSEN, XIN-QUAN ZHAO* \\ AND THE LATE BJØRN O. EGGUM \\ Danish Institute of Animal Science, Department of Nutrition, Research Centre Foulum, \\ PO Box 39, DK-8830 Tjele, Denmark
}

(Received 7 September 1995 - Revised 7 October 1996 - Accepted 8 October 1996)

\begin{abstract}
The present work was undertaken to study the energy value of a mixture of acetic, propionic and butyric acids (0.682: $0.226: 0.092)$ infused intracaecally in growing pigs. A basal diet low in fibre (42 g NSP/kg DM) was given at below the requirement for maximum weight gain. In six 2-week periods, $\mathbf{N}$ and energy balance measurements in eight growing pigs were carried out with and without infusion of short-chain fatty acids (SCFA). Heat production was measured using open-circuit chambers and the concentration of SCFA in faeces was determined. Less than $1 \%$ of the infused SCFA was excreted in faeces illustrating the capacity of the hind-gut to absorb and metabolize SCFA. Infusion of SCFA did not affect the digestibility of nutrients and energy. However, $N$ retention increased demonstrating that SCFA are an energy source for protein gain when pigs are fed at below the requirement of energy. Increased $\mathrm{CH}_{4}$ production together with an increased excretion of branched-chain fatty acids in faeces suggested that there was a higher microbial activity in the hind-gut during infusion. The partial utilization of the infused energy in SCFA was 0.821. A small proportion of the infused energy in SCFA was retained in protein (0.099) and a considerable amount was retained as fat (0.722).
\end{abstract}

Short-chain fatty acids: Fermentation: Heat production

The significance of hind-gut fermentation in pig nutrition is well established, especially when diets high in fermentable fibrous materials are given (Just et al. 1983a; Hoffman et al. 1990; Zhu et al. 1993; Jørgensen et al. 1996). The presence of dietary and endogenous residues in the large intestine leads to development of a diversified microflora. The large intestine is the major site for microbial fermentation resulting in the production of gas, lactic acid and short-chain fatty acids (SCFA) (Jensen \& Jørgensen, 1994). Barcroft et al. (1944) demonstrated that SCFA, of which acetate, propionate and butyrate are dominant, were absorbed from the caecum and colon of sheep, pigs, rats, rabbits and ponies by measuring the SCFA concentration in the blood vessels draining the large intestine. SCFA in the hind-gut are rapidly absorbed, predominantly by simple passive diffusion (McNeil $e t$ al. 1978; Rechkemmer et al. 1988; Fleming et al. 1991; Latymer et al. 1991) and absorption seems to be independent of luminal pH (Engelhardt et al. 1989). Some SCFA are metabolized at the site of absorption (Høverstad, 1986), but most colon-derived SCFA are cleared by the liver (Rérat et al. 1987; Yen et al. 1989).

In single-stomached animals, products of microbial fermentation, i.e. SCFA, can contribute a substantial amount of energy to the animal (Argenzio \& Southworth 1974; Just

\footnotetext{
* Visiting scientist from the Northwest Institute of Biology, The Chinese Academy of Sciences, Xining, Qinghai, 810001, China.
} 
et al. 1983a). The colonic fermentation of digesta results in a lower energetic utilization than that for carbohydrates which are digested and absorbed as monosaccharides from the small intestine. This difference is due to additional losses as $\mathrm{H}_{2}$ and $\mathrm{CH}_{4}$ as well as fermentation heat, together with a lower efficiency of utilization of SCFA in the intermediary metabolism of the organism. How efficiently the energy in the SCFA produced is utilized is a matter of dispute. For acetate, efficiency estimates range between 0.60 and 0.79 (Jentsch et al. 1968; Roth et al. 1988; Gädegen et al. 1989) and for propionate $0.71-0.75$ (Roth et al. 1988; Gädegen et al. 1989).

In a previous experiment we found that when a high-fibre diet was given, $460 \mathrm{~g}$ more organic matter was fermented daily in the hind-gut, compared with pigs fed on a low-fibre diet (Jørgensen et al. 1996). The net disappearance of carbohydrates together with the theoretical production of SCFA given by Miller \& Wolin (1979) suggested that SCFA production was as high as $4.2 \mathrm{~mol} / \mathrm{d}$.

The present report describes a study in which SCFA were infused into the caecum of growing pigs and the energy value was measured in a respiration plant. The pigs were fed on a low-fibre diet and the molar proportions of the infused solution resembled those of the fermentation products in the hind-gut of pigs fed on a high-fibre diet. The variables studied in the present work include the effect of infusion on digestibility as well as on protein and energy metabolism.

\section{MATERIALS AND METHODS}

\section{Animals and surgical procedure}

Eight barrows from two litters, with an average weight of $30 \mathrm{~kg}$, were obtained from the National Institute of Animal Science pig herd (Foulum, Denmark). Caecum cannulation was performed on the pigs at $35 \mathrm{~kg}$, after they had been starved for $24 \mathrm{~h}$. The pigs were sedated with an intramuscular injection, in the neck, of a mixture of $0.05 \mathrm{mg}$ atropine sulphate (Nycomed DAK, Copenhagen, Denmark), 3.6 mg azaperone (Stresnil ${ }^{\text {TM }}$, Janssen Pharmaceutica, Beerse, Belgium) and $0.25 \mathrm{mg}$ midazolam (Dormicum, Hoffmann-La Roche, Basel, Switzerland) per kg body weight. At 20 min later, anaesthesia was induced by intravenous injection of $4.0 \mathrm{mg}$ metomidat hydrochloride (Hypnodil $^{\mathrm{TM}}$, Janssen Pharmaceutical) per $\mathrm{kg}$ body weight into an ear vein. The pigs were intubated and brought under general anaesthesia using a gas mixture of halothane (Halothane Laboratories, North Augusta, SC, USA) and, as carrier, $\mathrm{O}_{2}-\mathrm{N}_{2} \mathrm{O}(1: 2$, v/v) A balloon Foley catheter (16 Ch, $5.3 \mathrm{~mm}$; Rüsch, Kernen, Germany) was inserted into the caecum 50-100 mm from the apex opposite the ileo-caecal valve and fastened with two pursestring sutures. The catheter was exteriorized on the upper right flank of the pig. The balloon catheter was taped to the back of the pig to ensure formation of a tight tissue seal. Following surgery, the pigs were returned to their holding pens and had free access to water but were starved that same day. To alleviate possible pain, two analgesics were administered. The pigs were given an intramuscular injection, in the neck, of $1.4 \mathrm{mg}$ peditin hydrochloride (Pedidin, Nycomed DAK) per $\mathrm{kg}$ body weight as soon as they regained consciousness. At $6 \mathrm{~h}$ later, an intramuscular injection of $0.01 \mathrm{mg}$ buprenophin hydrochloride (Temgesic ${ }^{\circledR}$, Reckitt \& Colman, Hull, Humberside) per kg body weight was given. Antimicrobial treatment of $20 \mathrm{mg}$ benzylpenicillin (Streptocillin ${ }^{\circledR}$, Boehringer Ingelheim Agrovet, Hellerup, Denmark) per kg body weight was applied for $3 \mathrm{~d}$ postoperatively. The body weight at the start of the experiment was 55.6 (SD 1.8) kg and after the experiment 121.0 (SD 4.4) $\mathrm{kg}$. 
Table 1. Dietary ingredients and chemical composition of the basal diet

\begin{tabular}{lr}
\hline \hline & \\
Ingredient (g/kg) & 243.0 \\
Barley & 563.1 \\
Wheat starch & 92.7 \\
Fish meal & 39.7 \\
Casein & 30.0 \\
Soyabean oil & 10.9 \\
Dicalcium phosphate & 13.6 \\
Monocalcium phosphate & 3.0 \\
Sodium chloride & 2.0 \\
Mineral and vitamin mixture* & 2.0 \\
Chromic oxide (marker) & 154.2 \\
Chemical composition (g/kg DM) & 57.6 \\
Protein (N x 6.25) & 694.9 \\
HCl-fat & 42.0 \\
Starch & 41.6 \\
NSP & 18.46 \\
Ash & Gross energy (MJ/kg DM) \\
\hline
\end{tabular}

HCl-fat, hydrochloric acid-fat.

* Supplied ( $/ \mathrm{kg}$ diet): retinol acetate $1376 \mu \mathrm{g}$, cholecalciferol $25 \mu \mathrm{g}$, dl- $\alpha$-tocopherol acetate $50 \mu \mathrm{g}$, menadione $2 \mathrm{mg}$, riboflavin $4 \mathrm{mg}$, D-pantothenic acid $10 \mathrm{mg}$, cyanocobalamin $0.02 \mathrm{mg}, \mathrm{FeSO}_{4} .7 \mathrm{H}_{2} \mathrm{O} 250 \mathrm{mg}, \mathrm{ZnO} 100 \mathrm{mg}, \mathrm{Mn}_{3} \mathrm{O}_{4}$ $36 \mathrm{mg}, \mathrm{CuSO}_{4} .5 \mathrm{H}_{2} \mathrm{O} 80 \mathrm{mg}, \mathrm{KI} 260 \mu \mathrm{g}, \mathrm{Na}_{2} \mathrm{SeO}_{3} 660 \mu \mathrm{g}$.

\section{Diet and infusate}

The composition of the diet, shown in Table 1, was similar to that used in a previous study (Jørgensen et al. 1996). The diet was formulated to supply the pigs with all necessary nutrients while causing a minimum of fermentation in the hind-gut. Barley was, however, added to improve the feed structure and palatability and $\mathrm{Cr}_{2} \mathrm{O}_{3}$ was added as a digestibility marker.

The SCFA infusate was prepared as a mixture of acetate, propionate and butyrate in the molar ratio $0.682: 0.226: 0.092$, i.e. $1.00 \mathrm{~mol}$ acetate $/, 0.33 \mathrm{~mol}$ propionate $/ \mathrm{l}$ and 0.14 mol butyrate/l, in total $1.47 \mathrm{~mol}$ SCFA/l solution (Table 2 ). Of the carboxylic groups, $80 \%$ were neutralized to obtain a physiological $\mathrm{pH}(5 \cdot 2)$ of the infusate. The neutralizing agents were $\mathrm{Ca}^{++}, \mathrm{Na}^{+}$and $\mathrm{K}^{+}$in a molar ratio of $9: 4: 10$, i.e. $0.23 \mathrm{~mol} \mathrm{CaCO} / 1,0.20 \mathrm{~mol}$ $\mathrm{NaOH} / 1$ and $0.51 \mathrm{~mol} \mathrm{KOH} / \mathrm{l}$, all reagents of analytical grade.

\section{Experimental procedure}

The study involved eight pigs. For practical reasons the experiment was carried out in two blocks. In six $9 \mathrm{~d}$ periods, $\mathrm{N}$ and energy balances were carried out with each pig with and without infusion of SCFA. The pigs were fed twice daily with $1.61 \mathrm{~kg} \operatorname{diet}(25.87 \mathrm{MJ} / \mathrm{d})$ in period 1 and feed intake was gradually increased to $1.97 \mathrm{~kg}$ diet $(32.47 \mathrm{MJ} / \mathrm{d})$ in period 6 . The daily feed intake was kept below the requirement for maximum weight gain (Just et al. $1983 \mathrm{~b}$ ) The average daily caecal infusion was 2.64 (SD 0.72) $\mathrm{mol} \mathrm{SCFA/d}$ through the caecal catheter at a rate of 1.24 (SD 0.34) $\mathrm{ml} / \mathrm{min}$ with a peristaltic infusion pump (Multifix; Bie \& Berntsen, Rødovre, Denmark). On day 1 in each period the pigs were placed in stainless-steel metabolism cages and the infusion was initiated. The first $2 \mathrm{~d}$ were regarded as an adaptation period and the rate of infusion was gradually increased. On day 3 the metabolism cages together with the pigs were wheeled into the respiration chambers and quantitative collection of urine and faeces as well as measurement of heat production took 
Table 2. Amount of short-chain fatty acids (SCFA) infused into the caecum of pigs and the effect on faeces dry matter and faecal output of SCFA

(Mean values with their standard errors for eight pigs)

\begin{tabular}{|c|c|c|c|}
\hline Infusion... & - & + & SEM \\
\hline \multicolumn{4}{|l|}{ Infused } \\
\hline Solution infused $(\mathrm{kg} / \mathrm{d})$ & $\mathbf{0}$ & 1.77 & \\
\hline Acetate $(\mathrm{mmol} / \mathrm{d})$ & $\mathbf{0}$ & 1787 & \\
\hline Propionate $(\mathrm{mmol} / \mathrm{d})$ & 0 & 592 & \\
\hline Butyrate $(\mathrm{mmol} / \mathrm{d})$ & $\mathbf{0}$ & 240 & \\
\hline Total SCFA (mmol/d) & 0 & 2619 & \\
\hline Dry matter in faeces $(\mathrm{g} / \mathrm{kg})$ & $666^{\mathrm{a}}$ & $483^{b}$ & $14 \cdot 1$ \\
\hline \multicolumn{4}{|l|}{ SCFA output in faeces (mmol/d) } \\
\hline Acetate & $6.4^{b}$ & $20 \cdot 0^{\mathrm{a}}$ & 1.9 \\
\hline Propionate & $1 \cdot 1^{b}$ & $5 \cdot 4^{2}$ & 0.5 \\
\hline Iso-butyrate & $0.3^{b}$ & $0.9^{\mathrm{a}}$ & $0 \cdot 1$ \\
\hline Butyrate & $0.6^{\mathrm{b}}$ & $2 \cdot 0^{\mathbf{a}}$ & 0.2 \\
\hline Iso-valerate & $0.2^{\mathrm{b}}$ & $0.6^{\mathrm{a}}$ & 0.1 \\
\hline Valerate & $0.1^{\mathrm{b}}$ & $0.4^{\mathrm{a}}$ & $0 \cdot 1$ \\
\hline Total SCFA & $8.7^{b}$ & $29 \cdot 4^{\mathrm{a}}$ & 2.6 \\
\hline \multicolumn{4}{|c|}{ SCFA concentration in faeces $(\mathrm{mmol} / \mathrm{kg}$ ) } \\
\hline Acetate & $42 \cdot 2^{\mathrm{b}}$ & $89 \cdot 5^{a}$ & 9.4 \\
\hline Propionate & $7 \cdot 2^{\mathrm{b}}$ & $24 \cdot 7^{\mathrm{a}}$ & 2.6 \\
\hline Iso-butyrate & $1.8^{\mathrm{b}}$ & $3 \cdot 9^{\mathrm{a}}$ & 0.3 \\
\hline Butyrate & $4 \cdot 0^{b}$ & $9.8^{\mathrm{a}}$ & 1.4 \\
\hline Iso-valerate & $1 \cdot 3^{\mathrm{b}}$ & $2.7^{\mathrm{a}}$ & 0.2 \\
\hline Valerate & $0.9^{b}$ & $2 \cdot 0^{\mathrm{a}}$ & 0.2 \\
\hline Total SCFA & $57 \cdot 6^{\mathrm{a}}$ & $132 \cdot 7^{\mathrm{a}}$ & $13 \cdot 4$ \\
\hline
\end{tabular}

a,b Values in the same row with different superscript letters were significantly different $(P<0.05)$.

place over the next $3 \mathrm{~d}$. After $2 \mathrm{~d}$ rest where the pigs were kept in the respiration chamber there followed $2 \mathrm{~d}$ without infusion with quantitative collection of faeces and urine together with measurement of heat production. In between periods the pigs were allowed $5 \mathrm{~d}$ on the floor in pens for exercise and adaptation to the new level of food intake. Heat production was estimated from gas exchange in two open-circuit respiration chambers. The chambers and procedures are described in detail by Jørgensen et al. (1996). The temperature in the respiration chambers was kept at $20(\mathrm{SD} 0.7)^{\circ}$, the relative humidity at 0.63 (SD 0.034) and a $12 \mathrm{~h}$ (06.00-18.00 hours) light-dark cycle was employed.

\section{Analytical methods}

$\mathrm{Cr}_{2} \mathrm{O}_{3}$ and organic acid determinations were performed on wet materials. All other analyses were carried out on freeze-dried materials except for the diets. DM content of the diet, ileal digesta and faeces was determined by oven-drying at $105^{\circ}$ for $20 \mathrm{~h}$. Protein $(\mathrm{N} \times 6.25)$ was determined by a modified Kjeldahl method (Kjell-Foss 16200 Autoanalyser; Foss Electric A/S, Hillerød, Denmark) and energy by bomb calorimetry (IKA-C 400; Janke \& Kunthel, KG IKA-Werk, Heitersheim, Germany). Ash was analysed according to the Association of Official Analytical Chemists (1975) while fat was extracted with diethyl ether after acid-hydrolysis (Stoldt, 1952). $\mathrm{Cr}_{2} \mathrm{O}_{3}$ was determined using the method of Schürch et al. (1950). C in the diet, faeces and urine was measured as described by Neergaard et al. (1969). Starch was analysed by the enzymic method reported by Bach Knudsen et al. (1993). Total NSP was determined using a modification of the method of Theander \& Aman (1979) as described by Bach Knudsen et al. (1993). 
Total SCFA and lactate were measured by a modification of a capillary GC method (Richardson et al. 1989) as described by Jensen et al. (1995).

\section{Calculations and statistical analysis}

Metabolizable energy (ME) includes energy losses from both urine and $\mathrm{CH}_{4}$ where calculations of energy lost in urine are based on urinary $\mathrm{N}$ (Just et al. 1983c). The $\mathrm{C}$ and $\mathrm{N}$ balance method (CN method) was used to calculate heat production (Brouwer, 1965). All calculations of gas exchange were carried out as the average of the three (infusion periods) $24 \mathrm{~h}$ or the two (control periods) $24 \mathrm{~h}$ respiration measurements. ANOVA was done using the general linear model procedure (Statistical Analysis Systems, 1987), with pig, period and infusion as main effects. Sums of squares were partitioned into single degree of freedom contrasts to examine the linear and quadratic effect of time (period). The slopes for each animal and treatment relating to live weight were compared with zero by onesample $t$ test and hence the average slopes were compared by paired $t$ test.

\section{RESULTS}

\section{Short-chain fatty acid molar proportions}

The health of the pigs was good throughout the study. During the entire experiment the pigs had an average daily gain of 748 (SD 21) $\mathrm{g}$. In a few cases (five out of forty-eight balances) the infusion resulted in diarrhoea, consequently these balances were not used in the calculations. However, infusion of SCFA did affect faecal DM (Table 2) which was lowered from $666 \mathrm{~g} / \mathrm{kg}$ to $483 \mathrm{~g} / \mathrm{kg}$ when SCFA were infused. The molar proportions of the SCFA in faeces changed from 80:13:7 (acetate : propionate : butyrate) in pigs fed on the basel diet to $73: 20: 7$ when SCFA were infused, which was close to the molar proportions in the SCFA infusate $(68: 23: 9)$. The infusion of chemical energy in SCFA relative to the dietary amount of ME corresponded to 0.098 (SD 0.023). The absolute amount of energy infused increased from $2.27 \mathrm{MJ} / \mathrm{d}$ in period 1 to $3.32 \mathrm{MJ} / \mathrm{d}$ in period 6 . There was only a minor increase in the faecal output of total SCFA, although significant $(P<0 \cdot 001)$, from $8.7 \mathrm{mmol} / \mathrm{d}$ when no infusion took place to $29.4 \mathrm{mmol} / \mathrm{d}$ with infusion. This was less than $1 \%$ of the infused SCFA, showing the capacity of the hind-gut to absorb or metabolize SCFA. The concentration of lactic acid in faeces was, in most cases, below the detection level.

\section{Digestibility and retention of protein and fat}

Digestibities of DM and energy were not affected by infusion of SCFA $(P>0.05)$, whereas protein digestibility was significantly affected $(P<0.05)$ (Table 3 ). However, the absolute difference for protein digestibility was negligible. The retention of protein was increased when SCFA were infused. As neither protein intake nor protein digestibility changed, the higher protein retention caused an improved protein utilization (protein retained/protein digested). As expected, fat retention increased (from 182 to $234 \mathrm{~g} / \mathrm{d}$ ) when SCFA were infused into the caecum. No time trend on digestibility in the experimental period from 60 to $120 \mathrm{~kg}$ live weight was detected.

Protein and lipid retention values during the experimental periods are shown in Fig. 1. Both daily protein and lipid retention increased significantly $(P<0.01)$ with live weight when SCFA were infused into the caecum. Without infusion no effect of live weight on 
Table 3. Effect of short-chain fatty acids infusion into the caecum of pigs on digestibility and retention of protein and fat*

(Mean values with their pooled standard error for eight pigs)

\begin{tabular}{|c|c|c|c|}
\hline Infusion ... & & + & SEM \\
\hline \multicolumn{4}{|l|}{ Digestibility } \\
\hline Protein & $89.8^{a}$ & $89 \cdot 3^{b}$ & 0.17 \\
\hline Dry matter & 90.0 & 89.7 & $0 \cdot 14$ \\
\hline Energy & 93.1 & 93.2 & 0.09 \\
\hline \multicolumn{4}{|l|}{ Protein balance } \\
\hline Protein intake $(\mathrm{g} / \mathrm{d})$ & 250 & 250 & - \\
\hline Protein retained $(\mathrm{g} / \mathrm{d})$ & $152^{b}$ & $165^{\mathrm{a}}$ & 1.70 \\
\hline Protein retained/protein digested & $0.681^{b}$ & $0.741^{\mathrm{a}}$ & 0.007 \\
\hline Fat retained $(\mathrm{g} / \mathrm{d})$ & $182^{b}$ & $234^{a}$ & $3 \cdot 1$ \\
\hline
\end{tabular}

a,b Values in the same row with different superscript letters were significantly different $(P<0.05)$.

* For details of procedures, see pp. 746-748.

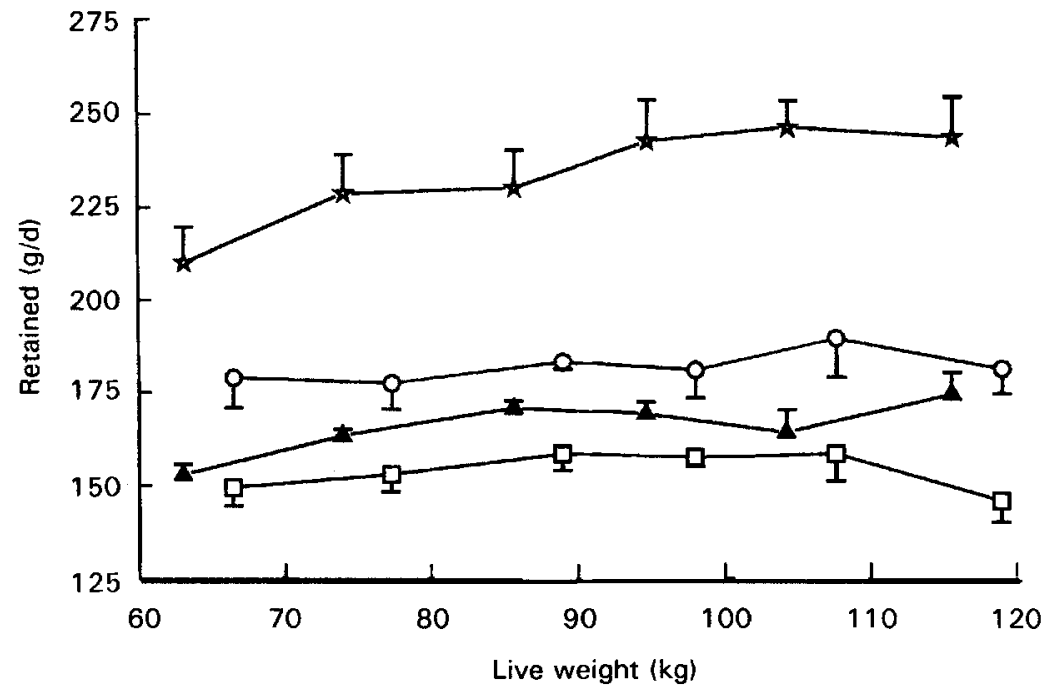

Fig. 1. Retained protein $(\boldsymbol{A}, \square)$ and lipid $(\boldsymbol{\omega}, O)$ in pigs either receiving infusion of short-chain fatty acids into the caecum $(\boldsymbol{\Lambda}, \hat{*})$ or without infusion $(\square, O)$ during the experimental periods. Values are means with their standard errors represented by vertical bars. For details of procedures, see pp. 746-748.

retained lipid was detected, however a quadratic effect was observed on protein retention. There was no significant difference when comparing the slopes for + infusion and - infusion.

\section{Energy metabolism}

Feed intake was kept constant in each period; the average daily feed intake is shown in Table 4. However, the daily amount of gross energy includes the amount of chemical energy from the infused SCFA. During infusion the pigs received on average $2.83 \mathrm{MJ}$ more $\mathrm{ME}$ per $\mathrm{d}$ than when no infusion took place. Because of the improved protein utilization the 
Table 4. Effect of short-chain fatty acids infusion into the caecum of pigs on energy balance* (Mean values with their pooled standard error for eight pigs)

\begin{tabular}{lccc}
\hline \hline Infusion ... & - & + & SEM \\
\hline Feed intake (kg/d) & 1.78 & 1.78 & \\
Gross energy (MJ/d) & $29.97^{\mathrm{b}}$ & $32.96^{\mathrm{a}}$ & 0.089 \\
Digested energy (MJ/d) & $27.88^{\mathrm{b}}$ & $30.72^{\mathrm{a}}$ & 0.088 \\
Metabolizable energy (MJ/d) & $27.32^{\mathrm{b}}$ & $30.22^{\mathrm{a}}$ & 0.090 \\
Urine energy (MJ/d) & $0.53^{\mathrm{a}}$ & $0.45^{\mathrm{b}}$ & 0.010 \\
$\mathrm{CH}_{4}$ energy (MJ/d) & $0.03^{\mathrm{b}}$ & $0.05^{\mathrm{a}}$ & 0.002 \\
Heat production (MJ/d) & $16.44^{\mathrm{b}}$ & $16.97^{\mathrm{a}}$ & 0.087 \\
Retained energy (MJ/d) & $10.87^{\mathrm{b}}$ & $13.25^{\mathrm{a}}$ & 0.126 \\
Retained energy in fat (MJ/d) & $7.24^{\mathrm{b}}$ & $9.31^{\mathrm{a}}$ & 0.122 \\
Retained energy in protein (MJ/d) & $3.63^{\mathrm{b}}$ & $3.94^{\mathrm{a}}$ & 0.041 \\
\hline \hline
\end{tabular}

a,b Values in the same row with different superscript letters were significantly different $(P<0.05)$.

* For details of procedures, see pp. 746-749.

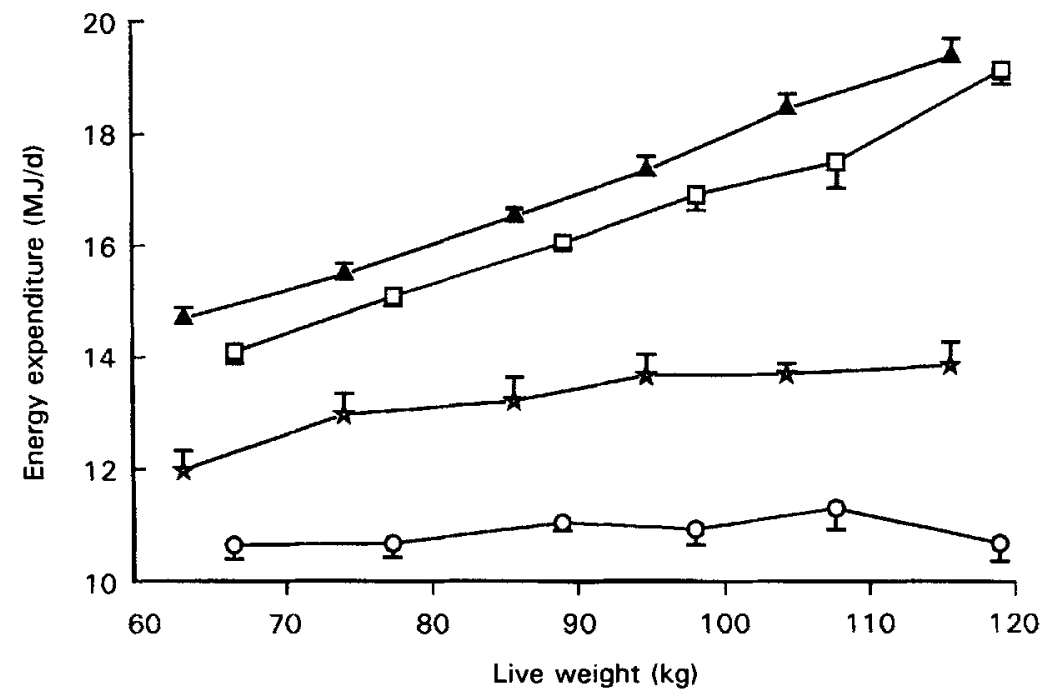

Fig. 2. Energy expenditure of pigs receiving infusion of short-chain fatty acids into the caecum or without infusion during the experimental periods. ( $\triangle$ ), Heat production with infusion; ( $\square$ ) heat production without infusion; ( retained with infusion; $(O)$, energy retained without infusion. Values are means with their standard errors represented by vertical bars.

amount of $\mathrm{N}$, and therefore energy, excreted in urine decreased during infusion. The absolute amount of energy in the $\mathrm{CH}_{4}$ produced was small but increased significantly with the infusion $(P<0.01)$. Infusion of SCFA affected the production, but to a lesser degree than energy retention. The heat production increased linearly during the entire experiment (Fig 2). When SCFA were infused the amount of energy retained increased with live weight compared with control (-infusion) where retained energy was unchanged. Thus, the difference between the slopes was significant $(P<0.05)$. The amount of retained energy, relative to $\mathrm{ME}$, increased slightly leaving a larger part of $\mathrm{ME}$ to be dissipated as heat. 
Table 5. Effect of short-chain fatty acids infusion into the caecum of pigs on energy utilization* (Mean values with their pooled standard errors for eight pigs)

\begin{tabular}{lccc}
\hline \hline Infusion ... & - & + & SEM \\
\hline Energy \% of DE as: & & & \\
ME & $98 \cdot 0^{\mathrm{b}}$ & $98.4^{\mathrm{a}}$ & 0.04 \\
Urine energy & $1.9^{\mathrm{a}}$ & $1.5^{\mathrm{b}}$ & 0.03 \\
CH energy & $0.1^{\mathrm{b}}$ & $0.2^{\mathrm{a}}$ & 0.01 \\
ME (MJ/kg DM) & $16.86^{\mathrm{b}}$ & $18.63^{\mathrm{a}}$ & 0.05 \\
& & & \\
Utilization of ME & & & \\
HP/ME & $0.601^{\mathrm{a}}$ & $0.561^{\mathrm{a}}$ & 0.003 \\
RE/ME & $0.399^{\mathrm{b}}$ & $0.439^{\mathrm{a}}$ & 0.003 \\
RE-fat/RE & $0.664^{\mathrm{b}}$ & $0.701^{\mathrm{a}}$ & 0.004 \\
RE-protein/RE & $0.336^{\mathrm{a}}$ & $0.299^{\mathrm{b}}$ & 0.004 \\
\hline \hline
\end{tabular}

$\mathrm{DE}$, digestible energy; $\mathrm{ME}$, metabolizable energy; $\mathrm{HP}$, heat production; RE, retained energy; RE-fat, retained energy in fat; RE-protein, retained energy in protein.

${ }^{\mathrm{a}, \mathrm{b}}$ Values in the same row with different superscript letters were significantly different $(P<0.05)$.

* For details of procedures, see pp. 746-749.

The effect of infusion of SCFA on the utilization of energy is shown in Table 5. The energy excreted in urine and $\mathrm{CH}_{4}$ accounted for less than $2 \%$ of $\mathrm{ME}$, although the effect was significant $(P<0.05)$. Relative to $\mathrm{ME}$, heat production decreased and consequently the amount of energy available for retention increased.

\section{Efficiency of infused short-chain fatty acids}

The utilization of the energy in infused SCFA, estimated by regression, is shown in Table 6. The metabolizability of SCFA was 0.977 with a standard error of estimate (SE) of 0.021 and was thus higher than the apparent digestibility of 0.954 (SE 0.030). The higher metabolizability than digestibility was caused by a reduced excretion of energy in urine $(-0.028)$ when SCFA were infused. The influence on $\mathrm{CH}_{4}$ excretion was small but increased by 0.004 compared with the infused energy. The partial utilization of the infused energy for retention was 0.821 , however, a small part was retained as protein (0.099) leaving the amount retained as fat as 0.722 .

Table 6. Energy efficiency of short-chain fatty acids infused into the caecum of pigs estimated as the regression coefficient from the equation: $\mathrm{Y}_{\mathrm{ij}}=\mu+$ pig $_{i}+$ period $_{j}+b \times$ infused energy

\begin{tabular}{lcc}
\hline & Estimate (b) & Standard error of estimate \\
\hline Digested energy/GE & 0.954 & 0.020 \\
Energy in urine/GE & -0.028 & 0.005 \\
Energy in $\mathrm{CH}_{4} / \mathrm{GE}$ & 0.004 & 0.001 \\
Metabolizable energy/GE & 0.977 & 0.021 \\
Heat production/GE & 0.156 & 0.040 \\
Retained energy/GE & 0.821 & 0.044 \\
Retained energy in fat/GE & 0.722 & 0.044 \\
Retained energy in protein/GE & 0.099 & 0.019 \\
\hline
\end{tabular}

GE, gross energy of infused short-chain fatty acids. 


\section{DISCUSSION}

\section{Short-chain fatty acid molar proportions}

The amount of SCFA infused into the caecum was on average 2619 (SD 708) mmol/d (Table 2). This corresponds to $2.99 \mathrm{MJ} / \mathrm{d}$, that is, less than the difference in digested or fermented energy between pigs fed on low- or high-fibre diets in a previous study (Jørgensen et al. 1996). In that study, 22.1\% of the energy measured as digested was fermented by microbes in the hind-gut. In the present study a higher infusion rate induced diarrhoea, which occurred in a few cases. We found that the infused amount of SCFA was not far from a maximum limit under the present experimental conditions. Thus, the infusion rate was adjusted to the maximum amount tolerated by pigs before the onset of diarrhoea. The amount of SCFA infused was similar to findings by Gädegen et al. (1989). In contrast, Roth et al. (1988) infused 2-3 times more SCFA into the caecum of adult sows (160-200 kg live weight). The infusion of SCFA in the present study caused a lower DM content in the faecal material but the faecal DM content was less affected by infusion than when pigs were fed on a diet high in fibre (Jørgensen et al. 1996).

The concentrations of SCFA in faeces when no infusion took place were similar to concentrations measured in pigs fed on diets containing wheat and oat fractions (Bach Knudsen et al. 1991). The SCFA concentration in faeces when no infusion of SCFA took place resembled the SCFA concentration in caecum fluid, which also seems to be very similar in several mammalian species (Rechkemmer et al. 1988).

Of the infused SCFA, less than $1 \%$ was excreted in faeces, which is in agreement with the results of Roth et al. (1988) and Gädegen et al. (1989). Similarly, Jentsch et al. (1968) and Imoto \& Namioka (1983) fed pigs orally with acetic acid or triacetin and found that they were almost completely absorbed. Thus, there is apparently no difference in absorption of SCFA from the digestive tract whether they are given orally or infused into the caecum. In studies with infusion of different types of starch as well as complete diets into the caecum of pigs, Just et al. (1981) found that the infused nutrients were digested almost as well as if they had been given orally. This demonstrates the large fermentative capacity of the hind-gut.

\section{Digestibility and retention of protein and fat}

Although the infusion of SCFA did not have any effect on either protein or energy digestibility (Table 3), utilization of digested protein appeared to increase. When dietary energy is a limiting factor for maximum growth, an additional supply of energy may act as a stimulus to protein accretion in growing animals. Protein accretion requires energy both for synthesis of peptide bonds as well as for other processes of growth associated with protein accretion. Thus Fuller \& Crofts (1977) have demonstrated an increase in N retention in growing pigs with increased intake of starch. An increase in $\mathrm{N}$ retention also appeared when acetate was added to a diet for young growing pigs (Imoto \& Namioka, 1983). The increase in protein retention with infusion of SCFA in the present experiment could be attributed to an extra supply of energy (SCFA). The pigs without infusion were fed at above their maintenance requirement but below the energy requirement for maximum gain (Just et al. 1983b).

\section{Energy metabolism}

The importance of fermentation to man and other single-stomached animals lies in the products formed and their fate in the body. When SCFA were infused into the caecum, less 
than $1 \%$ was excreted in the faeces. However, apparent digestibility was 0.954 (Table 6). This is in agreement with results found by Roth et al. (1988) and Gädegen et al. (1989) under comparable experimental conditions. The results from the present study reveal that some SCFA were metabolized by the colonic microflora. Although microbial activity (as expressed by ATP concentration, see Bach Knudsen et al. 1991; Jensen \& Jørgensen, 1994) was not measured in the present study, increased microbial activity was indicated by a small but significantly $(P<0.05)$ higher $\mathrm{CH}_{4}$ production by SCFA-infused animals. A further indication of increased microbial activity was a higher concentration of the branched-chain fatty acids iso-butyric and iso-valeric acids. These acids are derived from microbial fermentation of branched-chain amino acids (Macfarlane et al. 1986) from protein residues not absorbed in the small intestine. When diets high in fibre are given, there is hypertrophy and enlargement of the hind-gut (Demigné \& Rémésy, 1985; Jørgensen et al. 1996), which might increase energy expenditure (Yen et al. 1989). A direct physical effect of fibres cannot be ruled out, but SCFA themselves could affect intestinal function (Kripke et al. 1989). Butyrate is considered to be the preferred respiratory fuel for colonocytes and the primary trophic factor in the colon (Roediger, 1982; Kripke et al. 1989).

SCFA in the circulatory system have been ascribed various effects. Dietary fibre, especially the water-soluble fibres, that ferment more completely than water-insoluble fibres, can lower serum lipids. Thus, propionate has been studied for a potential serum lipid lowering effect (Beaulieu \& McBurney, 1992). Furthermore, it has been shown that infused acetate is recycled and metabolized into more complex compounds such as glycerideconjugated bile acids (Latymer et al. 1991). It has been demonstrated that the appearance of SCFA in the portal blood draining the intestine corresponds to the arrival of the first undigested fraction of the meal into the hind-gut (Rérat et al. 1987). The absorption is predominantly considered to be by passive diffusion (Rechkemmer et al. 1988; Fleming $e t$ al. 1991) and seems to be independent of luminal pH (Engelhardt et al. 1989). Acetate is the dominating fatty acid from hind-gut fermentation and is believed to be the major precursor of biosynthesis of lipids. Correspondingly, the major effect of the infusion of SCFA and the subsequent absorption in the organism was increased energy retention (mainly as fat) and to a lesser extent increased heat production.

\section{Efficiency of infused short-chain fatty acids}

Whereas acetate can be used for the biosynthesis of higher lipids, propionate for gluconeogenesis, and butyrate for the formation of ketone bodies, the eventual fate of these SCFA is oxidation for energy. The reduced loss of urinary $\mathbf{N}$ with increasing infusion of SCFA (Table 6) indicates that the energy supply to the pigs was limiting relative to the potential for protein accretion. Besides, this increased protein utilization caused a higher ME value of the infused SCFA solution than the DE value.

The net efficiency of the infused SCFA (retained energy/gross energy) was 0.821 , of which fat retention accounted for 0.722 . These values are within the range of earlier published results. In the study by Jentsch et al. (1968) the utilization of acetic acid fed orally to adult pigs amounted to $0 \cdot 60$. In experiments where SCFA were infused into the caecum of sows, the efficiency of utilization was estimated to be between 0.68 and 0.79 (Roth et al. 1988; Müller et al. 1991). Similar efficiencies were measured by Gädegen $e$ t al. (1989) in growing pigs. The efficiency of the SCFA obtained in the present study was just lower than the efficiency of 0.86 that can be calculated from the conversion efficiency suggested in a recent review by Livesey (1992). 
The support of the Danish Agricultural and Veterinary Research Council is gratefully acknowledged. The authors would like to thank Peter Theil and Benny Thomasen for their assistance with infusion, and the technical staff at the Department of Nutrition for their qualified care of the animals.

\section{REFERENCES}

Argenzio, R. A. \& Southworth, M. (1974). Sites of organic acid production and absorption in the gastrointestinal tract of the pig. American Journal of Physiology 228, 454-460.

Association of Official Analytical Chemists (1975). Official Methods of Analysis, 11th ed. Washington, DC: Association of Official Analytical Chemists.

Bach Knudsen, K. E., Jensen, B. B., Andersen, J. O \& Hansen, I. (1991). Gastrointestinal implications in pigs of wheat and oat fractions. 2. Microbial activity in the gastrointestinal tract. British Journal of Nutrition 65, 233248.

Bach Knudsen, K. E., Jensen, B. B. \& Hansen, I. (1993). Digestion of polysaccharides and other major components in the small and large intestine of pigs fed on diets consisting of oat fractions rich in $\beta$-D-glucan. British Joumal of Nutrition 70, 537-556.

Barcroft, J., McAnally, R. A. \& Phillipson, A. T. (1944). Absorption of volatile acids from the alimentary tract of the sheep and other animals. Journal of Experimental Biology 20, 120-132.

Beaulieu, K. E. \& McBurney, M. I. (1992). Changes in pig serum lipids, nutrient digestibility and sterol excretion during cecal infusion of propionate. Journal of Nutrition 122, 241-245.

Brouwer, E. (1965). Report of Sub-committee on Constants and Factors. In Energy Metabolism. EAAP Publication no. 11, pp. 441-443 [K. L. Blaxter, editor]. London: Academic Press.

Demigné, C. \& Rémésy, C. (1985). Stimulation of absorption of volatile fatty acids and minerals in cecum of rats adapted to very high fiber diet. Joumal of Nutrition 115, 53-60.

Engelhardt, W. v., Rönnau, K., Rechkemmer, G. \& Sakata, T. (1989). Absorption of short-chain fatty acids and their role in the hindgut of monogastric animals. Animal Feed Science and Technology 23, 43-53.

Fleming, S. E., Choi, S. Y. \& Fitch, M. D. (1991). Absorption of short-chain fatty acids from the rat cecum in vivo. Journal of Nutrition 121, 1787-1797.

Fuller, M. F. \& Crofts, R. M. J. (1977). The protein-sparing effect of carbohydrate. 1. Nitrogen retention of growing pigs in relation to diet. British Journal of Nutrition 38, 479-488.

Gädegen, D., Breves, G. \& Oslage, H. J. (1989). Efficiency of energy utilization of intracaecally infused volatile fatty acids in pigs. In Energy Metabolism of Farm Animals. EAAP Publication no. 43, pp. 115-118 [Y. van der Honing and W. H. Close, editors]. Wageningen: Pudoc.

Hoffmann, L., Jentsch, W. \& Schiemann, R. (1990). Energieumsatzmessungen am adulten Schwein bei Verfütterung von Rationen mit Kartoffelstärke, Kartoffeln, Rüben, Pressschnitzeln und Großfuttermitteln als Zulagen zu einer Grundration. 1. Energieumsatz und Energieverwertung (Measurement of the energy metabolism of adult pigs after feeding of rations with potato starch, potatoes, beets, sugar beet pulp and roughage as supplements to a basic ration. 1. Energy metabolism and energy utilization). Archives of Animal Nutrition 40, 191-207.

Høverstad, T. (1986). Studies of short-chain fatty acid absorption in man. Scandinavian Journal of Gastroenterology 21, 257-260.

Imoto, S. \& Namioka, S. (1983). Nutritive value of acetate in growing pigs. Journal of Animal Science 56, 858866.

Jensen, B. B \& Jørgensen, H. (1994). Effect of dietary fiber on microbial activity and microbial gas production in various regions of the gastrointestinal tract of pigs. Applied and Environmental Microbiology 60, 1897-1904.

Jensen, M. T., Cox, R. P. \& Jensen, B. B. (1995). Microbial production of skatole in the hind gut of pigs fed different diets and its relation to skatole deposition in backfat. Animal Science 61, 293-304.

Jentsch, W., Schiemann, R. \& Hoffmann, L. (1968). Modellversuche mit Schweinen zur Bestimmung der energetischen Verwertung von Alkohol, Essig- und Milchsäure (Model experiments with pigs for determining the energy utilization of alcohol, acetic acid and lactic acid). Archiv für Tierernährung 18, 352-357.

Jørgensen, H., Zhao, X. Q. \& Eggum. B. O. (1996). The influence of dietary fibre and environmental temperature on the development of the gastrointestinal tract, digestibility, degree of fermentation in the hind-gut and energy metabolism in pigs. British Journal of Nutrition 75, 365-378.

Just, A., Fernández, J. A. \& Jørgensen, H. (1981). The digestive capacity of the caecum-colon and the value of the nitrogen absorbed from the hind gut for protein synthesis in pigs. British Journal of Nutrition 46, 209-219.

Just, A., Fernández, J. A. \& Jørgensen, H. (1983a). The net energy value of diets for growth in pigs in relation to the fermentative processes in the digestive tract and the site of absorption of the nutrients. Livestock Production Science 10, 171-186.

Just, A., Jørgensen, H. \& Fernández, J. A. (1983b). Maintenance requirement and the net energy value of different diets for growth in pigs. Livestock Production Science 10, 487--506. 
Just, A., Jørgensen, H. \& Fernández, J. A. (1983c). Forskellige foderstoffers kemiske sammenscetning, fordøjelighed, energi- og proteinvardi til svin (The Chemical Composition, Digestibility, Energy and Protein Value of Different Feedstuffs for Pigs). Report no. 556. Copenhagen: National Institute of Animal Science.

Kripke, S. A., Fox, A. D., Bergman, J. M., Settle, R. G. \& Rombeau, J. L. (1989). Stimulation of intestinal mucosal growth with intracolonic infusion of short-chain fatty acids. Journal of Parenteral and Enteral Nutrition 13, 109-116.

Latymer, E. A., Keal, H. D. \& Low, A. G. (1991). Absorption and metabolism of $\left[\mathrm{U}^{14}{ }^{14} \mathrm{C}\right]$ acetic acid in growing pigs. Animal Production 52, 331-336.

Livesey, G. (1992). The energy values of dietary fibre and sugar alcohols for man. Nutrition Research Reviews 5 , 61-84.

Macfarlane, G. T., Cummings, J. H. \& Allison, C. (1986). Protein degradation by human intestinal bacteria. Journal of General Microbiology 132, 1647-1656.

McNeil, N. I., Cummings, J. H. \& James, W. P. T. (1978). Short chain fatty acid absorption by the human large intestine. Gut 19, 819-822.

Miller, T. L. \& Wolin, M. J. (1979). Fermentations by saccharolytic intestinal bacteria. American Journal of Clinical Nutrition 32, 164-172.

Müller, H. L., Kirchgessner, M. \& Roth, F. X. (1991). Energetische Efficienz eines intracaecal infundierten Essigsäure-Propionsäuregemisches bei Sauen (Energetic efficiency of a mixture of acetic and propionic acids in sows). Journal of Animal Physiology and Animal Nutrition 65, 140-145.

Neergaard, L., Petersen, C. B. \& Thorbek, G. (1969). Carbon determination in biological materials related to respiration trials. Zeitschrift für Tierphysiology, Tierernährung und Futtermittelkunde 25, 302-308.

Rechkemmer, G., Rönnau, K. \& Engelhardt, W. v. (1988). Fermentation of polysaccharides and absorption of short chain fatty acids in the mammalian hindgut. Comparative Biochemistry and Physiology 90A, 563-569.

Rérat, A., Fiszlewicz, M., Guisi, A. \& Vaugelade, P. (1987). Influence of meal frequency on postprandial variations in the production and absorption of volatile fatty acids in the digestive tract of conscious pigs. Journal of Animal Science 64, 448-456.

Richardson, A. J., Calder, A. G., Stewart, C. S. \& Smith, A. (1989). Simultaneous determination of volatile and non-volatile acidic fermentation products of anaerobes by capillary gas chromatography. Letters in Applied Microbiology 9, 5-8.

Roediger, W. E. W. (1982). Utilization of nutrients by isolated epithelial cells of the rat colon. Gastroenterology $83,424-429$.

Roth, F. X., Kirchgessner, M. \& Müller, H. L. (1988). Energetische Verwertung von intracaecal infundierter Essig- und Propionsäure bei Sauen (Energetic utilization of intracaecally infused acetic and propionic acids in sows). Journal of Animal Physiology and Animal Nutrition 59, 211-217.

Schürch, A. F., Lloyd, L. E. \& Crampton, E. W. (1950). The use of chromic oxide as an index for determining the digestibility of a diet. Journal of Nutrition 50, 628-636.

Statistical Analysis Systems (1987). SAS/STAT Guide for Personal Computers, version 6 ed. Cary, NC: Statistical Analysis Systems Institute, Inc.

Stoldt, W. (1952). Vorslag zur Vereinheitlichung der Fettbestimmung in Lebensmitteln (Suggestions to standardize the determinations of fat in foodstuffs). Fette, Seifen, Anstrichmittel 54, 206-207.

Theander, O. \& Åman, P. (1979). Studies on dietary fibre. 1. Analysis and chemical characterization of watersoluble and water-insoluble dietary fibres. Swedish Journal of Agricultural Research 9, 97-106.

Yen, J. T., Nienaber, J. A., Hill, D. A. \& Pond, W. G. (1989). Oxygen consumption by portal vein-drained organs and by whole animal in conscious growing swine. Proceedings of the Society for Experimental Biology and Medicine 190, 393-398.

Zhu, J. Q., Fowler, V. R. \& Fuller, M. F. (1993). Assessment of fermentation in growing pigs given unmolassed sugar-beet pulp: a stoichiometric approach. British Journal of Nutrition 69, 511-525. 